\title{
Desire of Pregnancy and Fertility after Myomectomy: about 76 Patients Operated at Ouakam Military Hospital (Dakar, Senegal) between 2009 and 2013
}

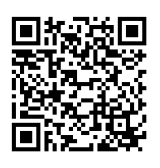

\author{
MM Niang*, BN Sene Badji, B Diop, Y Wane and CT Cisse \\ Department of Gyneacology and Obstetrics, Institute of Social Hygiene, Sénégal
}

Submission: February 22, 2018; Published: March 13, 2018

*Corresponding author: Mouhamadou Mansour, Department of Gyneacology and Obstetrics, Institute of Social Hygiene, Sénégal, Email: mansniang@hotmail.com

\begin{abstract}
Summary
Objective: To evaluate fertility after myomectomy by laparotomy in Ouakam Military Hospital.

Patients and methods: This was a retrospective, descriptive and analytical patients who underwent myomectomy to Ouakam Military Hospital between 2009 and 2013 and who were subsequently tried to achieve pregnancy. The primary outcome was obtaining a pregnancy after myomectomy.
\end{abstract}

Results: Three hundred and forty five patients underwent myomectomy by laparotomy between 2009 and 2013. Patients were a mean age of 37.2 years with an average parity 1. The mean duration of follow-up after myomectomy was 26 months. One hundred - twenty patients $(34.8 \%)$ were contacted again. Seventy - six (63.3\%) have attempted to obtain a pregnancy. Dix - nine patients (25\%) achieved a pregnancy. Pregnancies were achieved spontaneously. Most patients (89.5\%) were delivered at term. Two patients (10.5\%) had a miscarriage. Fertility after myomectomy is significantly correlated with patient age $(\mathrm{p}=0.042)$, its parity $(\mathrm{p}=0.004)$ and fertility before myomectomy $(\mathrm{p}=0.012)$.

Conclusion: Advanced age ( $\geq 39$ years), nulliparity and infertility before myomectomy are factors of poor prognosis for obtaining a pregnancy after myomectomy by laparotomy.

Keywords: Fertility; Myomectomy; Pregnancy

\section{Introduction}

Uterine fibroid is a benign proliferation of the myometrium. It affects 20 to $25 \%$ of women during the period of genital activity [1]. In Senegal, hospital studies found respectively $37.25 \%$ and $58.8 \%$ of gynecological surgeries $[2,3]$.

The myoma - fertility relationship is still controversial. Apart from the existence of a true obstruction of the genital tract by endocavitary fibroid, theoretically the fibroid should not prevent conception if the other fertility conditions are normal. This controversy also concerns the impact of myomectomy on the subsequent fertility of women who have benefited from it. In this case, two questions arise: can the removal of myomas increase the fertility potential? Can myomectomy impair fertility, particularly through complications such as uterine adhesions $[4,5]$.
In Senegal, to our knowledge, very little work has been done on this issue. Thus, we proposed to conduct this study whose objectives were to determine the epidemiological profile of patients, to identify the factors associated with fertility after myomectomy and to specify the pregnancy rate recorded after myomectomy.

\section{Patients and Methods}

It is a descriptive and analytical retrospective study concerning a cohort of patients wishing to become pregnant after a laparotomy myomectomy between 2009 and 2013 at the Military Hospital of Ouakam. Patients were contacted by phone and reviewed in consultation. A questionnaire was prepared and completed during the interrogation after free and informed consent. The following parameters were analyzed: age, parity, 
marital status, reasons for consultation, paraclinical aspects (hemogram, pelvic ultrasound, hysterosalpingography, vaginal sampling, spermogram), indications of myomectomy and fertility after myomectomy. The patients included were those who had a myomectomy during the study period and who were interested in pregnancy.

The data was recorded and analyzed using the Epi info version 6 software. The correlation examination and the significant risks that existed between the variables during the analysis were performed using adequacy and comparison tests. The Chi-square test was used for comparisons. The tests were significant as soon as the associated probability was less than $5 \%$. We used the null hypothesis if $\alpha$ was less than 0.05 . If the null hypothesis was rejected, we proceeded to the analysis of the relation. Otherwise, the relationship was simply removed from the study.

\section{Results}

\section{Characteristics of the patients}

The patients were between 25 and 46 years old, with an average of 37.2 years. Twenty-six of them $(34.2 \%)$ were over 39 years old. Parity ranged from 0 to 5 , with an average of 1 . Fiftyfour patients were nulliparous $(71.1 \%)$. They were married in $94.7 \%$ of cases.

Table 1: Distribution by indications $(\mathrm{N}=76)$.

\begin{tabular}{|c|c|c|}
\hline Indications & Number & Frequency (\%) \\
\hline Infertility & 30 & 39,5 \\
\hline Disorders of the menstrual cycle & 25 & 32,9 \\
\hline Pelvic pain & 15 & 19,7 \\
\hline $\begin{array}{c}\text { Abdominal-pelvic mass with compression } \\
\text { signs }\end{array}$ & 6 & 7,9 \\
\hline Total & 76 & 100 \\
\hline
\end{tabular}

\section{Fertility after myomectomy}

Within an average of 18 months, $25 \%$ of patients (19/76) got a pregnancy. The majority of pregnancies (89.5\%) evolved normally with term delivery. We also recorded 2 spontaneous abortions in the first trimester (10.5\%). Sixteen patients (84.6\%) delivered by caesarean section, including $69.2 \%$ of prophylactic caesareans. There were 3 vaginal deliveries (15.4\%).

Table 2: Factors influencing fertility after myomectomy $(N=76)$.

\begin{tabular}{|c|c|c|c|c|}
\hline Pregnancy Obtained & Pregnancy not Obtained & Total & p & 0,042 \\
\hline Age (years) & & & 5 & 14 \\
\hline$[25-29]$ & $2(40 \%)$ & $3(60 \%)$ & 31 & \\
\hline$[30-34]$ & $6(42,9 \%)$ & $8(57,1 \%)$ & 26 & 0,004 \\
\hline$[35-39]$ & $7(22,6 \%)$ & $24(77,4 \%)$ & & \\
\hline$>39$ & $4(15,4 \%)$ & $22(84,6 \%)$ & 54 & \\
\hline Parity & & & & \\
\hline Nulliparous & $8(14,8 \%)$ & $46(85,2 \%)$ & $5(45,4 \%)$ & \\
\hline
\end{tabular}


Journal of Gynecology and Women's Health

\begin{tabular}{|c|c|c|c|c|}
\hline Multiparous & $5(45,4 \%)$ & $6(54,6 \%)$ & 11 & 0,012 \\
\hline Prior infertility & & & & 50 \\
\hline Yes & $8(16 \%)$ & $42(84 \%)$ & 26 & \\
\hline No & $11(42,3 \%)$ & $15(57,7 \%)$ & & \\
\hline
\end{tabular}

\section{Discussion}

\section{Characteristics of the patients}

Our patients were between 25 and 36 years old, with an average of 37 years. This age is comparable to the average age of occurrence of fibroids found in the Wathie series [3]. The average age of fibroid onset, its rate of growth over time, and its single or multiple character remain controversial $[6,7]$. Parity ranged from 0 to 5, with an average of 1 . Nulliparous and primiparous women accounted for $80 \%$ of our sample. Lumbiganon [8] found that with more than 5 deliveries, the risk decreases with OR = $0.21(95 \%, \mathrm{CI}=0.12-0.35)$. According to Parazzini [9], the late age of the last pregnancy decreases the risk with $\mathrm{OR}=0.5(0.3$ $0.8)$. Thus, pregnancy is a protective factor, as is the high number of gestation [10]. The predominance of nulliparas confirms the role of the estrogen in the genesis of uterine fibroids through exposure to prolonged hyperestrogeny. Our results confirm the hypothesis of Lumbiganon [8] who argues that the risk reduction of uterine fibroids is linked to parity and that this risk decreases with the number of pregnancies.

\section{Pregnancy after myomectomy}

During the study period, 76 patients (63.3\%) had a desire of pregnancy. Within an average of 18 months, 19 of them (25\%) were pregnant. The majority of pregnancies $(68.4 \%)$ had evolved normally with term delivery. We also had 2 spontaneous abortions in the first trimester (10.5\%) and 4 pregnancies were still in progress $(21.1 \%)$. Caesarean section was the most common mode of delivery (84.6\%). It was most often programmed $(69.2 \%)$. We recorded $15.4 \%$ of births by natural ways. In the Roux study [11], $13 \%$ of pregnancies and $6 \%$ of miscarriages were found. This difference results from the fact that the size of the Roux series [11] was 15 patients; thus, the result of the statistical analyzes must be interpreted carefully because of the limited size of its sample. The impact of myomas on fertility can be evaluated by comparing women with myoma to women free from any fibromatous pathology consulting for a desire for pregnancy, or by comparing the results of myomectomy and abstention in patients with a desire for pregnancy. A single prospective study comparing a population of 106 infertile women with myomas to a population of 106 infertile women without myoma found a significantly decreased design rate in the presence of myomas ( $11 \%$ versus $25 \%, p=0.02)$ [12]. The size, number and location of myomas have not been specified in this study but it allows demonstrating the responsibility of myomas on fertility in case of spontaneous procreation (NP4).

\section{Factors influencing fertility after myomectomy}

In our series, fertility after myomectomy was significantly influenced by the age of the patient $(p=0.042)$. In patients over 39 , the pregnancy rate after myomectomy was only $15.4 \%$ compared with $42.9 \%$ between 30 and 34 years ( $p=0.042$ ). Most patients over 39 years old (80\%) did not have pregnancy after myomectomy. In women, fertility decreases with age; this decrease is especially marked after 30 years and accelerates between 35 and 40 years, so that fertility is almost zero at 45 years. The main mechanism is the quantitative and qualitative alteration of the ovarian reserve, which accelerates after 38 years old [11]. Similarly, it is noted in the literature that the rate of miscarriage increases with age: $15 \%$ at $30,20 \%$ at 37 and $27 \%$ at 42 [11]. In our study, we recorded an abortion rate of $10.5 \%$, or 2 out of 19 patients. They were 38 and 40 years old. In the Roux study [11], all the patients who were able to obtain a pregnancy had already given birth before the myomectomy, against 57.9\% in our study. Probably, nulliparity is a factor of bad prognosis; because the nulliparous group had more infertile patients, 78\% of cases of infertility. Infertility before myomectomy is a factor of poor prognosis for the subsequent pregnancy. In our series, infertility was present in 50 patients $(65.8 \%)$. It was most often primary infertility (60\%). The duration of infertility ranged from 1 to 20 years, with an average of 6 years. In these patients, only 8 $(16 \%)$ were able to get pregnant after the myomectomy. The role of myomas in infertility is not clear. The prevalence of myomas appears to be greater in the population of infertile women [11]. The prevalence of myomas at routine second trimester screening ultrasonography is $2.7 \%$; while it reaches $12.6 \%$ in infertile women managed in vitro fertilization (IVF) [11]. The explanation that could be given to this result is that infertility would probably be multifactorial. Thus, the only myomectomy would not be enough to restore fertility. This brings us to the question of the relevance of a myomectomy for infertility. Thus, in these patients, if a myomectomy is decided, it would be necessary to first make a complete assessment of fertility for the purpose of detecting the other associated factors. It would also be helpful to inform patients that myomectomy alone is rarely enough to restore fertility.

\section{Conclusion}

The myomectomy - infertility relationship is still controversial. The results of our study do not allow us to decide one way or the other. In order to have more arguments, a multicenter study would be needed to investigate infertile women who have been fully explored.

\section{References}

1. Graves WP (1993) Tumors of the uterus. In: Curtis AH (Ed.), Obstet Gynecol, WB Saunders, Philadelphia, USA.

2. Beye S (1998) Les fibromes utérins à la Clinique Chirurgicale du CHU de Dakar: à propos de 140 cas opérés en 2 ans. Thèse Med, Dakar, 46 : 60-95. 
3. Wathie FK (2007) Les fibromes utérins au Centre de Santé Roi Baudouin de Guédiawaye : à propos de 148 cas opérés. Thèse Med, Dakar, 111 : 56-91.

4. Agostini A, Colette E, Ronda I, Bretelle F, Cravello I, et al. (2005) Vaginal myomectomy. Encycl Med Chir Gynécol Obstét pp. 371-376.

5. Benhaim Y, Ducarme G, Madelenat P, Darai E, Poncelet C (2005) Les limites de la myomectomie coelioscopique. Gynecol Obstet Fertil 33 : 44-49.

6. Bourdela $\mathrm{N}$, bonnefoya $\mathrm{C}$, Jardona $\mathrm{K}$, Da inesb $\mathrm{D}$, Tognazzaa $\mathrm{E}$, et al. (2011) Myomectomie hystéroscopique : récidive et enquête de satisfaction à court et long terme. J Gynecol Obstet Biol Reprod 40: 116 -122 .

7. Lefevrey (1993) Fibromes utérins. Editions Techniques - Encycl Med Chir Paris, France, Gynecol 570-A-10.

8. Lumbiganon P, Rugpo S (1995) Protective effect of depotmedroxyprogesterone acetate on surgically treated uterine leiomyomas: a multicentrie case-control study. Br J Obstet Gynecol 103: 909 - 914 .

9. Parazzini F, La vecchia C, Negri E, Cecchetti G, Fedele L (1988) Epidemiologic characteristcs of women with uterine fibroids: a casecontrol study. Obstet. Gynecol 72(6): 853-857.

10. Rongieres C (1999) Epidémiologie du fibrome utérin : facteurs de risques et fréquence. Impact en Santé Publique. J Gynecol Obstet Biol Reprod 28: 701-706.

11. Roux I, Faivrea E, Trichot C, Donnadieua AC, Fernandez H, et al. (2011) Fertilité après myomectomie par laparotomie pour les femmes de plus de 38 ans. J Gynecol Obstet Biol Reprod 40: 123-129.

12. Legendrea G, Brun JL, Fernandez H (2011) Actualisation de la prise en charge des myomes. Place des myomectomies en situation de conception spontanée ou chez la femme désireuse de préserver sa fertilité. J Gynecol Obstet Biol Reprod 40: 875 - 884.

\section{Your next submission with Juniper Publishers will reach you the below assets}

- Quality Editorial service

- Swift Peer Review

- Reprints availability

- E-prints Service

- Manuscript Podcast for convenient understanding

- Global attainment for your research

- Manuscript accessibility in different formats

( Pdf, E-pub, Full Text, Audio)

- Unceasing customer service

Track the below URL for one-step submission https://juniperpublishers.com/online-submission.php 